\title{
The Underachievement of Portuguese-Canadian Youth: An Ongoing Phenomenon
}

\author{
Fernando Nunes, PhD \\ Associate Professor, Mount Saint Vincent University, Halifax, NS
}

\begin{abstract}
For nearly 4 generations, the youth of the Portuguese-Canadian community have been underachieving academically and dropping out of school earlier and in greater numbers, than most other youth. As a result, the Portuguese in Canada have had disproportionately low levels of frequency in post-secondary education, which are often comparable to those of Canada's Aboriginals. The author discusses some of the reasons for the perpetuation of this phenomenon: The ignoring of the underachievement of Luso-Canadians by anti-racism education scholars; the dismissal of existing research data and unwillingness to acknowledge the effects of systemic barriers, by the community's own political and business leadership; the belief amongst many that Portuguese-Canadian parents are at fault for the perpetuation of underachievement; the positioning of the Portuguese-Canadian community as a working-class, little-educated group; as well as a lack of programs that are specifically targeted to PortugueseCanadian youth.
\end{abstract}

Keywords: academic achievement, Portuguese-Canadian, education, minorities, drop-out

\section{Introduction: Background and Opinions Regarding this Problem}

Research has indicated that, on average, the children of immigrants to Canada are achieving, in school, in levels that are roughly equal to their Canadian-born counterparts (Abada, Hou \& Ram, 2009; Statistics Canada, 2008a; Worswick, 2001). However, in recent decades, scholars and community activists have highlighted the stubborn persistence of school drop-out and lack of entrance to post-secondary education, amongst a number of Canada's immigrant and minority communities (Anisef, Brown, Phythian, Sweet \& Walters, 2010; Finney, Childs \& Wismer, 2011; McKell, 2010).

This is the case with Portuguese-Canadian youth (also known as Luso-Canadians), of both Canadian-born and immigrant origin. For nearly 4 generations, the young people of this community have been performing at significantly lower academic levels, disproportionately represented in Special Education programs and dropping out of school earlier and in greater numbers, than most other youth (Anisef, Brown, Phythian, Sweet \& Walters, 2008; Brown 1999, 2010; Brown, Cheng Yau \& Ziegler, 1992; Cheng \& Yau 1999; Cheng, Tsuji, Yau \& Ziegler, 1989; Cheng, Yau \& Ziegler 1993; Matas \& Valentine 2000; Noivo, 1997; Nunes 1998, 2000; Ornstein 2000; 2006a; 2006b; Santos, 2004). Luso-Canadians in Toronto have also been more likely to say that they will not attend university, lack confidence in their ability to succeed in post-secondary education, work the longest average hours of parttime work and spend the fewest hours per week on homework (Cheng \& Yau, 1999; Cheng, Yau \& Ziegler, 1993; Larter, Cheng, Capps \& Lee, 1982; Project Diploma, 2004).

Partly as a consequence to this ongoing dropout phenomenon, as well as the low levels of education of the immigrant generation, at the turn of the millennium only approximately $6 \%$ of all Luso-Canadians over the age of 15 had achieved a university degree (Matas \& Valentine, 2000). In fact, the Portuguese in Canada have traditionally had levels of frequency in post-secondary education which are comparable only to those of Canada's Aboriginals (Matas \& Valentine, 2000; Nunes, 1998, 2010; Statistics Canada, 2008b). This reality has led Michael Ornstein (2006a), in his report Ethnoracial Inequality in Toronto to describe Luso-Canadians as one of the groups "of most concern" (p. 51) and as suffering "extreme [educational] disadvantage" (p. 124-125).

Yet, the underachievement of Portuguese-Canadians has also largely been ignored by most education scholars, policy-makers, as well as the school system.

Firstly, this is a community of white, European origin amongst a dropout cohort that is today composed 
entirely of peoples of visible minority and non-European roots. This fact has often led anti-racist scholars and activists to ignore, or even dismiss, the case of the Portuguese as an aberration of social class disadvantage, or to assume that Luso-Canadian students are not affected by structural racist barriers. This omission is exacerbated by the fact that the Portuguese largely do not display many of the same social problems of these other groups, (for example, living disproportionately in poverty, disenfranchisement from society, higher rates of youth crimes, etc.) (Nunes, 1998).

Secondly, the underachievement problem seems to be one that is predominantly affecting PortugueseCanadian males. Census data indicates that while Portuguese men have been underrepresented in post-secondary institutions by approximately $30 \%$, Portuguese-Canadian females seem to be attending college and university in the same frequencies as other Canadian females (Giles, 2002; Nunes, 2005). This has often led community members to view this problem as the result of the errant choices of individual young Luso-Canadian males, rather than systemic barriers to education.

Thirdly, the community's underachievement issue is not necessarily visible, at street level. Today, there is an abundance of young Luso-Canadian professionals in the cities of Toronto and Montreal, as well as large numbers attending college and university. This is evident in the institutional completeness of the Toronto Portuguese community, the prevalence of Luso-Canadian student associations, as well as the great many doctors and lawyers, who are listed in the community telephone directory (Guia, 2014).

Finally, there has been an ongoing reluctance amongst many of the Luso-Canadian political and business leadership to acknowledge this problem, or to attribute the causes to systemic educational barriers. While representatives from groups such as the Aboriginal and African-Canadian communities have frequently and vigorously confronted school and government officials on the role of racist practices and policies in perpetuating the under-schooling of their youth, the same has not been the case amongst the Portuguese-Canadian leadership.

In fact, many amongst this group feel that this issue has its roots in disadvantaging "community attitudes" of not valuing education, on the part Portuguese-Canadian parents (Nunes, 1998, 2004). Those who make this assertion often affirm that this problem will eventually resolve itself, once the immigrant generation passes on. They cite, as evidence, the example of the Italians and Greeks (whose own underachievement has largely disappeared). Others have come forward to openly question the quality and veracity of the data, the research methods used, the interpretations of scholars, or to categorically assert that this is a problem that only exists within the Toronto community (for example see the panel discussion in Kitts, 2008). Some of these individuals are adamant that underachievement is no longer a problem in the community and point to the fact that the graduation rates of Luso-Canadians have improved tremendously over the decades. Yet still others warn that advocating with school and government officials about this problem will only serve to stigmatize Luso-Canadian youth and thus further perpetuate this issue.

\section{The Issue: What the Evidence Shows}

Unfortunately, the available research evidence serves neither to validate the beliefs of these individuals explained above, nor supports their positions.

Firstly, data on this phenomenon has been conducted over the decades, in various cities across Canada, by numerous scholars and detailed in diverse and updated sources, including school board reports and census data (up to the 2006 Census - the last with reliable data on ethnicity and education) (see Nunes, 2010). Some of this evidence has illustrated how this is a persistent, longstanding problem, and how stereotyping of Luso-Canadian youth as culturally- and educationally-deprived, by their teachers, has been prevalent since the 1960's.

Secondly, there is ample evidence that unfavourable and discriminatory school practices are important contributing factors to this problem. For example, various scholars have identified disadvantaging school rituals, practices, teachers' expectations and curriculum offerings - such as streaming - which have been found to discourage the education of Portuguese-Canadian youth (for example see Januario, 1992; McLaren, 1986; Nunes, 2004). Alternatively, at least one study from Britain has illustrated how significant improvements amongst Portuguese students can be achieved by the adoption of a number of school-based strategies that can help to overcome existing barriers to school success (Demie \& Lewis, 2010). 
More compelling evidence of the influence of school practices is the disproportionate numbers of the community's children in Toronto who have been placed in remedial Special Education. While some community members, or teachers, may affirm that the decision drop out of high school is influenced by coercive community attitudes, it is clear that the actions and attitudes of parents can have no influence in the assessment of large numbers of Luso-Canadian children as "learning disabled." In this regard, the school system must be implicated, both in the way that Luso-Canadian children are evaluated, as well as in its failure to provide alternative programs for those who are being wrongly placed.

Thirdly, although over the past decades, graduation rates of Portuguese-Canadian youth have improved from lows of $30-40 \%$ to approximately $66 \%$ (Brown, 2010), the same has also occurred amongst the youth of other groups. In fact, despite the fact that the graduation rates of Portuguese-speaking students in the Toronto District School Board have noticeably increased over time, these still remain $10 \%$ lower than the overall levels for the TDSB (76\%) (Brown, 2010; Presley \& Brown, 2011). This reality reflects the fact that today's cohorts of Luso-Canadian students (most of who live within predominantly working-class families) are studying alongside the offspring of the newer waves of better-educated immigrant parents. Higher parental education levels are one of the factors that have been found to be most associated with superior educational achievement (Abada, Hou \& Ram, 2008). Thus, relative to other children, Luso-Canadian youth continue to occupy roughly the same position as in previous decades.

Furthermore, the high visibility of professionals in the Toronto community does little to negate the ongoing underrepresentation of Luso-Canadians in middle- and upper-income positions. For example, the fact that Ontario currently has a Finance Minister who is of Luso-Canadian origin (Hon. Charles Sousa) in no way diminishes the reality that Portuguese-Canadians continue to be one of the most politically-underrepresented of Canada's large immigrant populations (Andrew, Biles, Siemiatycki, \& Tolley, 2008).

Finally, apart from anecdotal accounts by community members about their neighbours' intentions, no direct research evidence has ever surfaced to suggest that Portuguese-Canadian parents value entering the workforce over education. In contrast, scholars like Noivo (1997) and Januario (1992) reported how parents in their studies hoped that their children could acquire the education that they didn't achieve, or lamented the fact that their children had dropped out. Furthermore, in a study that I am currently completing (Nunes, F. Uncovering Barriers and Support Mechanisms in the Education of Portuguese-Canadian Youth) not one interviewee, out of a group of about 150 stated that their parents had discouraged their further education (Nunes, 2010, March 30). In fact, those youth who were failing in school described how their parents would habitually yell, hit, or threaten to put them to work, in an effort to get them to improve (Nunes, 2010, November 18).

However, what is clear from this study is how many Portuguese parents neither participate actively in their children's education nor have the skills to help them, with their educational issues. When serious problems arose, these parents often dealt with these difficulties by reacting in an authoritarian fashion or giving their children an ultimatum to either improve their school performance, or go to work (Nunes, 2010, November 18). Many of these were not engaging with the schools, in order to find alternative ways to help their children, nor were they exploring alternatives to entering the workforce, (for example, community college, tutoring, etc.).

\section{Discussion}

What is emerging from my research is that the positioning of the Portuguese-Canadian community and its youth as a working-class, little-educated group plays a major role in the perpetuation of this problem (Nunes, 2004). In the large cities of Toronto and Montreal, Portuguese-Canadian male youth are affected by existing educational barriers, the association of the community to a working-class role, the negative stereotyping of teachers and others, as well as by the ready availability of working-class jobs for young males, which give these youth an alternative to a difficult school process (the same do not exist for females). In the smaller communities of Vancouver, Halifax and Winnipeg there appears to be little negative stereotyping of the community or the educational progress of its youth. Consequently, youth in these smaller centres perceive themselves as coming from a rich and vibrant culture and as being unique amongst their peers. The lack of available working-class 
employment opportunities in cities like Halifax also means that education becomes a more attractive option for these youth.

The problem of underachievement is ultimately exacerbated by the lack of programs that are specifically geared to help Portuguese-Canadian students. Most ethno-specific programs that focus on at-risk youth, either offered by social service agencies, or Boards of Education, are geared towards visible-minority and Aboriginal youth. In fact, the only programs that specifically target Luso-Canadian youth are the On Your Mark tutoring program, which is run by Toronto's Working Women Community Centre and the student outreach programs of the York University and University of Toronto Portuguese Students' Associations. A drop-in program for at-risk youth focusing predominantly on Portuguese-Canadians, called the Dufferin Mall Youth Services, was housed in Toronto's Dufferin Mall, but had its funding cancelled a few years ago (Ferenc, 2011). Unfortunately, the closure of this program was met with deafening silence by most of the Portuguese-Canadian community leadership. This type of response is both a symptom, as well as a further enabler, of this community's difficult underachievement issue.

\section{Conclusion and Implications}

The persistence of underachievement across 4 generations of Luso-Canadian youth, along with the reluctance of the community's political and business leadership to acknowledge the role of structural and institutional barriers, will most likely serve to perpetuate this issue across subsequent generations. The consequences will most likely be the continuation of a lack of representation and voice for Luso-Canadians within the affairs of mainstream Canadian society, as well as the ongoing omission of the Portuguese from critical discussions of racist and exclusionary practices of the school system. This can only lead to the further absence of this group from the various equity initiatives, which directly result from these dialogues (for example, employment equity, anti-racist initiatives, etc.). Furthermore, with the passing of the immigrant and first generations, the assimilation of the newer generations into Canadian society and the lack of significant new immigration from Portugal, this issue will most likely fade from the public eye. This is particularly the case as the social, cultural and political impacts of the Portuguese in Canadian society become increasingly measured against those of the newer generations of better-educated, professionally credentialed immigrants and their descendants. The consequences of these changes for the community as a whole will increasingly matter much less than their effects on the prosperity and integration of individual Portuguese-Canadian families.

\section{References}

Abada, T., Hou, F. \& Ram, B. (2008). Group Differences in Educational Attainment Among the Children of Immigrants. Analytical Studies Branch, Research Paper (Catalogue no. 11F0019M - No. 308) Ottawa: Statistics Canada, Ministry of Industry.

Abada, T., Hou, F. \& Ram, B. (2009). Ethnic Differences in Educational Attainment among the Children of Canadian Immigrants. Canadian Journal of Sociology/Cahiers canadiens de sociologie. 34(1), 1-30.

Andrew, C., Biles, J., Siemiatycki, M. \& Tolley, E. (2008). Electing a Diverse Canada: The Representation of Immigrants, Minorities, and Women. Vancouver: UBC Press.

Anisef, P., Brown, R., Phythian, K., Sweet, R. \& Walters, D. (2008). Early School Leaving Among Immigrants in Toronto Secondary Schools. (Ceris Working Paper \# 67). Toronto: Ceris, the Ontario Metropolis Centre.

Anisef, P., Brown, R., Phythian, K., Sweet, R. \& Walters, D. (2010). Early School Leaving Among Immigrants in Toronto Secondary Schools. Canadian Review of Sociology/Review canadienne de sociologie, 47(2), $103-128$.

Brown, R. (1999). A Study of the Grade 9 Cohort of 1993, 1993-1998: The Last Grade 9 Cohort of the Toronto Board of Education. Report No. 229. Toronto: Academic Accountability, Toronto District School Board.

Brown, R. (2010). The Grade 9 Cohort of Fall 2004. Report No. 09/10-15. Toronto: Organizational Development 
Department, Research and Information Services, Toronto District School Board.

Brown, R. S., M. Cheng, M. Yau, and S. Ziegler. (1992). The 1991 Every Secondary Student Survey: Initial findings. (Report No. 200). Toronto: Research Services, Toronto Board of Education.

Cheng, M., \& M. Yau. (1999). The 1997 Every Secondary Student Survey: Detailed Findings. (Report No. 230). Toronto: Toronto District School Board.

Cheng, M., G. Tsuji, M. Yau, \& S. Ziegler. (1989). The Every Secondary Student Survey, Fall 1987. (Report No. 191). Toronto: Research Section, Toronto Board of Education.

Cheng, M., Yau, M., \& Ziegler, S. (1993). The 1991 Every Secondary Student Survey, Part II: Detailed Profiles of Toronto's Secondary School Students. (Report No. 204). Toronto: Research Services, Toronto Board of Education.

Demie, F. \& Lewis, K. (2010). Raising the achievement of Portuguese pupils in British schools: a case study of good practice. Educational Studies, 36(1), 95-109.

Ferenc, L. (2011, April 14). Young people lobby to save Dufferin Mall Youth Services. Toronto Star, downloaded on December $10, \quad 2014$ from http://www.thestar.com/news/gta/2011/04/14/young people lobby to save dufferin mall youth services.htm

Finnie, R., Childs, S. \& Wismer, A. (2011). Access to Post-Secondary Education Among Under-Represented and Minority Groups: Measuring the Gaps, Assessing the Causes. (Working Paper 2011-1) Ottawa, ON: University of Ottawa, Education Policy Research Initiative.

Giles, W. (2002). Portuguese Women in Toronto: Gender Immigration and Nationalism, Toronto, University of Toronto Press.

Guia Comercial Portugues (2014). Toronto: Tavares Publications, Ltd..

Januario, I. (1992). Portuguese-Canadian children in Elementary schools: Case studies in class and ethnicity. In G. Wells, A Huynh, I. Januario, M.L.Y. Lam, \& M. Schechter. (Eds.) Language and learning: Learners, Teachers and Researchers at Work, Vol II: Case studies of children from different ethno-linguistic communities (pp. 223-280). An occasional publication for teacher development.Toronto: Ontario Institute for Studies in Education.

Kitts, D. (Executive Producer) (2008, April 15). The Portuguese Paradox. The Agenda with Steve Paikin, [Television Broadcast, Current Affairs Program, Panel Discussion]. Toronto, ON: TV Ontario

Larter, S., Cheng, M., Capps, S. \& Lee, M. (1982). Post secondary plans of grade eight students and related variables (report \# 165). Toronto: The Board of Education for the City of Toronto, Research Department.

Matas, F., \& Valentine, J. (2000). Selected Ethnic Profiles on Educational Attainment. Strategic Research and Analysis. Ottawa: Multiculturalism Program, Department of Canadian Heritage.

McKell, L. (2010). Achievement Gap Task Force Draft Report. Toronto, ON: Toronto District School Board.

McLaren, P. (1986). Schooling as a ritual performance. London: Routledge \& Kegan Paul.

Noivo, E. (1997). Inside Ethnic Families: Three Generations of Portuguese- Canadians. Montréal: McGill-Queen's University Press.

Nunes, F. (1998). Portuguese-Canadians from Sea to Sea: A National Needs Assessment. Portuguese-Canadian National Congress.

Nunes, F. (2000). Portuguese-Canadians: A Profile from the 1991 Canadian Census. Gávea-Brown 21, p. 80-107. 
Nunes, F. (2004). Marginalization, social reproduction and academic underachievement: the case of the Portuguese community in Canada. In de Abreu, G., Cline, T. \& Lambert, H. (Eds.), The Education of Portuguese children in Britain: Insights from research and practice in England and overseas (pp. 167-210). Portugal: Ministry of Education.

Nunes, F. (2005) Gender Differences and Commonalities in the Integration of Luso-Canadians. In Marujo, M, Baptista, A. \& R. Barbosa. (Eds). The Voice and Choice of Portuguese Immigrant Women. University of Toronto, Department of Spanish and Portuguese, p. 149-155.

Nunes, F. (2010). Striking a Balance in Canada's Diversity Dialogue, Canadian Diversity 6 (2), 121-125.

Nunes, F. (2010, March 30). Barriers and supports in the schooling of Portuguese-Canadian youth: Questioning the myth of lack of parental support for education. Paper presented at the Migration Forum: Emigração/Comunidades - Emigration Communities. Toronto: Hart House, University of Toronto

Nunes, F. (2010, November 18). "There's something called a 'colher':"Portuguese-Canadian academic underachievement and parental approaches toward their children's schooling. Paper presented at the FerreiraMendes Portuguese-American Archives, Claire T. Carney Library, University of Massachusetts at Dartmouth, Dartmouth, MA, USA.

Ornstein, M. (2000). Ethno-Racial Inequality in the City of Toronto: An Analysis of the 1996 Census. Toronto: Access and Equity Unit, City of Toronto.

Ornstein, M. 2006a. Ethno-Racial Groups in Montréal and Vancouver, 1971- 2001: A Demographic and SocioEconomic Profile. Toronto: York University, Institute for Social Research.

Ornstein, M. (2006b). Ethno-Racial Groups in Toronto, 1971-2001: A Demographic and Socio-Economic Profile. Toronto: York University, Institute for Social Research.

Ornstein, M. (2006c). "Moving the Watermill: Collectively Addressing the Needs of Luso-Canadian 'At-Risk' Youth." Paper presented at a meeting with Chief Justice of Ontario Roy McMurtry and the Portuguese-Canadian National Congress. University of Toronto, Osgoode Hall (April 4).

Presley, A. \& Brown, R. (2011). Portuguese-Speaking Students in the TDSB: An Overview. Report No. 11/12-01. Toronto: Research and Information Services, Toronto District School Board.

Project Diploma. (2004). http://www.projectdiploma.com, Accessed November 30, 2014.

Santos, H. (2004). Portuguese-Canadians and Their Academic Underachievement in High School in British Columbia: The Case of an Invisible Minority. Master's thesis, Simon Fraser University.

Statistics Canada. (2008a). Children of Immigrants: How Well do they do in School? Education Matters. 81-004-XIE. Ottawa: ON, http://www.statcan.gc.ca/pub/81-004-x/200410/7422-eng.htm (Accessed November 28, 2014).

Statistics Canada. (2008b). 2006 Census Topic-based Tabulations. Ottawa: ON, Statistics Canada catalogue no. 97564-ХСВ2006007.

Worswick, C. (2001). School Performance of the Children of Immigrants in Canada, 1994-98.(Research Paper Series No.11F0019- No.178), Ottawa, ON: Statistics Canada, Analytical Studies Branch. 